\title{
Development of the Osteoblast Phenotype of Serial Cell Subcultures from Human Bone Marrow
}

\author{
Adalberto Luiz ROSA \\ Márcio Mateus BELOTI \\ Department of Oral and Maxillofacial Surgery and Periodontology, Faculty of Dentistry of Ribeirão Preto, \\ University of Sao Paulo, Ribeirão Preto, SP, Brazil
}

\begin{abstract}
Bone marrow cells have been used for testing biocompatibility of bone substitute materials that would be applied in maxillofacial and orthopedic surgeries. However, it remains unclear whether cells in serial subcultures retain the ability to differentiate into osteoblasts. The purpose of this study was to compare the development of osteoblast phenotype of serially passaged cells from human bone marrow. Cells from first to third passage were cultured $\left(2 \times 10^{4}\right.$ cells $/$ well $)$ in supplemented culture medium. Cells were incubated at $37^{\circ} \mathrm{C}$ in a humidified atmosphere of $5 \% \mathrm{CO}_{2}$ and $95 \%$ air. Cell attachment was assessed at 4 and $24 \mathrm{~h}$. At 7, 14 and 21 days, cell proliferation, cell viability, total protein content and alkaline phosphatase (ALP) activity were evaluated. Bone-like formation was evaluated at 14 and 21 days. Data were compared by two-way ANOVA and Duncan's multiple range test. Cell attachment, cell viability and total protein content were not affected by serial subcultures. However, serial subcultures did interfered negatively with osteoblast differentiation as shown by osteoblast parameters observed in second and third subcultures, such as continuous cell proliferation, lower ALP activity and bone-like formation in comparison to first subculture. Therefore, it is important to evaluate cell ability to growth and differentiate before selecting the cell population for studies that investigate the biocompatibility of materials to replace bone tissue.
\end{abstract}

Key Words: biocompatibility, human bone marrow, cell culture, osteoblast phenotype.

\section{INTRODUCTION}

In biomaterials research, the relationship between cells and their substrata has been widely investigated with the aim of maximizing the performance of implants placed into the body through maxillofacial and orthopedic surgeries by facilitating the integration between the implant and the biological system (1).

Bone cell culture systems have been largely used in studies with the goal of understanding biological events occurring at the bone tissue and biomaterial interface (2-4). Biocompatibility evaluations through cell cultures would be made using primary cell cultures because the biomaterials will interact with these cells after in vivo implantation (5). Moreover, cells derived from osteosarcoma cannot present total differentiation in vitro, while immortalized lineage can present different phenotypic expression of the cells from which they were originated (6).

Marrow stromal cells are nonhematopoietic multipotent stem-like cells that adhere to culture dishes (7). It is a heterogeneous population that contains osteogenic, fibroblastic and adipocytic cell lineages, and present extensive differentiation capacity (8). The expression of a particular cell phenotype in this culture system depends on the biological material manipulation and culture conditions, namely, culture medium, culture time and the presence of compounds that influence cell proliferation and differentiation (9). These characteristics have been identified in bone marrow cells from numerous species, including human being (10).

Studies involving interactions between cell culture

Correspondence: Prof. Dr. Adalberto L. Rosa, Departamento de Cirurgia e Traumatologia Buco-Maxilo-Facial \& Periodontia, Faculdade de Odontologia de Ribeirão Preto, USP, 14040-904 Ribeirão Preto, SP, Brasil. Tel: +55-16-3602-3980. Fax: +55-16-3633-0999. e-mail: adalrosa@forp.usp.br 
and biomaterials require an environment that allows osteoblast differentiation and a large number of cells. Because of the small amount of biological material available to obtain the primary culture, particularly of human origin, serial subcultures are often performed in order to have a sufficient number of cells (10). Although these cells have been used in large number of in vitro biocompatibility studies, it remains unclear whether cells in serial subcultures retain the ability to differentiate into osteoblasts. According to Coelho et al. (10), serial subcultures may result in loss of the osteoblast phenotype. In contrast, Bruder et al. (11) showed that cells derived from human bone marrow are able to undergo $38 \pm 4$ doublings in culture and still differentiate into osteoblasts. Therefore, before using cells from serial subcultures in in vitro studies, the evaluation of the phenotype is essential to select the adequate cell population (12).

The purpose of this study was to evaluate the development of the osteoblast phenotype in bone marrow cells from humans. Serially subcultured cells were cultivated under conditions that allowed osteoblast differentiation and the following parameters were evaluated: cell attachment, cell viability, cell proliferation, total protein content, alkaline phosphatase (ALP) activity and bone-like formation.

\section{MATERIAL AND METHODS}

Human bone marrow cells obtained from healthy male donors, 18-28 year-old, under approved research protocols of the Brazilian National Commission of Ethics in Research for human tissue specimens, were cultured in $\alpha$-minimum essential medium ( $\alpha$-MEM) (Gibco - Life Technologies, Grand Island, NY, USA), supplemented with $10 \%$ fetal bovine serum (Gibco), 50 $\mu \mathrm{g} / \mathrm{mL}$ gentamicin (Gibco), $0.3 \mu \mathrm{g} / \mathrm{mL}$ fungizone (Gibco), $10^{-7} \mathrm{M}$ dexamethazone (Sigma, St. Louis, MO, USA), $5 \mu \mathrm{g} / \mathrm{mL}$ ascorbic acid (Gibco), and $7 \mathrm{mM} \beta$ glycerophosphate (Sigma). Such culture conditions favored the development of osteoblast phenotype $(10,13)$. Cells were maintained until subconfluence.

Next, adherent cells from first to third subculture were harvested after treatment with $1 \mathrm{mM}$ EDTA (Gibco) and $0.25 \%$ trypsin (Gibco) and subcultured in 24-well culture plates (Falcon, Franklin Lakes, NJ, USA) in the same medium at a cell density of $2 \times 10^{4}$ cells per well. During the culture period, cells were incubated at $37^{\circ} \mathrm{C}$ in a humidified atmosphere of $5 \% \mathrm{CO}_{2}$ and $95 \%$ air, and the medium was changed every 3 or 4 days.

Cell Attachment. For evaluation of attachment, cells were cultured for 4 and $24 \mathrm{~h}$. Adherent cells were then enzymatically ( $1 \mathrm{mM}$ EDTA and $0.25 \%$ trypsin Gibco) released from the well and counted with a hemacytometer. Cell attachment was expressed as a percentage of the initial number of cells.

Cell Proliferation and Viability. For assessment of proliferation and viability, cells were cultured for 7 , 14 and 21 days, and then enzymatically $(1 \mathrm{mM}$ ethylenediaminetetraacetic acid, $1.3 \mathrm{mg} / \mathrm{mL}$ collagenase, and $0.25 \%$ trypsin) released from the well. Aliquots of these solutions of each well were incubated for $5 \mathrm{~min}$ with the same volume of $1 \%$ trypan blue (Sigma) that stains nonviable cells, and cells were counted with a hemacytometer. Cell proliferation was expressed as number of cells per well and cell viability was expressed as a percentage of the total number of cells counted at 7, 14 and 21 days, respectively.

Total Protein Content. The total protein content was calculated at 7, 14 and 21 days according to a modification of the Lowry method (14). The wells were filled with $2 \mathrm{~mL}$ of $0.1 \%$ sodium lauryl sulfate (Sigma). After $30 \mathrm{~min}, 1 \mathrm{~mL}$ of this solution from each well was mixed with $1 \mathrm{~mL}$ of Lowry solution (Sigma) and left for $20 \mathrm{~min}$ at room temperature. After this period, $0.5 \mathrm{~mL}$ of a solution of phenol reagent of Folin and Ciocalteau (Sigma) were added. This stood for $30 \mathrm{~min}$ at room temperature for color development. Absorbance was then spectrophotometrically measured (CE3021, Cecil, Cambridge, United Kingdom) at $680 \mathrm{~nm}$ and total protein content $(\mu \mathrm{g} / \mathrm{mL})$ was calculated from a standard curve. These data were normalized by the number of cells counted at 7, 14 and 21 days, respectively.

ALP Activity. ALP activity was assayed as the release of tymolphtalein from tymolphtalein monophosphate with a commercial kit (Labtest Diagnostica, Lagoa Santa, MG, Brazil), and the specific activity was calculated. Aliquots of the same solutions used for calculating the total protein content were assayed for measuring ALP activity. The absorbance was spectrophotometrically measured at $590 \mathrm{~nm}$ and ALP activity was calculated from a standard measure. Results were calculated and data were expressed as ALP activity ( $\mu$ mol tymophtaleine/h) normalized by the number of cells counted at 7, 14 and 21 days, respectively.

Bone-like Formation. At 14 and 21 days, attached cells were fixed in 3\% glutaraldehyde (Electron 
Microscopy Sciences, Washington, PA, USA) in a 0.1 $\mathrm{M}$ sodium cacodylate buffer (Electron Microscopy Sciences) for $2 \mathrm{~h}$ at room temperature and rinsed once in the same buffer. After fixation, the specimens were dehydrated through a graded series of alcohol and processed for staining with Alizarin red S (Sigma), which stains areas rich in calcium. The specimens were evaluated with an image analyzer (Image Tool University of Texas Health Science Center, San Antonio, TX, USA) and the amount of bone-like formation was calculated as a percentage of the total well area.

Data from this study are the representative results of two separate experiments in cell cultures established from two different bone marrow donors. For each subculture of each experiment, evaluations were carried out in quintuplicate $(n=5)$. Data were submitted to two-way analysis of variance (ANOVA) and Duncan's multiple range test when appropriate.

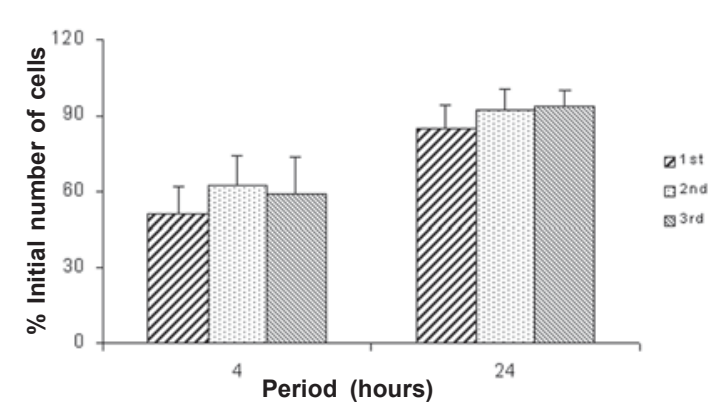

Figure 1. Cell attachment expressed as percentage of initial cell number at $4 \mathrm{~h}$ and $24 \mathrm{~h}$. Data are reported as means plus or minus the standard deviation $(n=5)$. There were no statistically significant differences among subcultures (1st, 2nd and 3rd) $(\mathrm{p}>0.05)$.

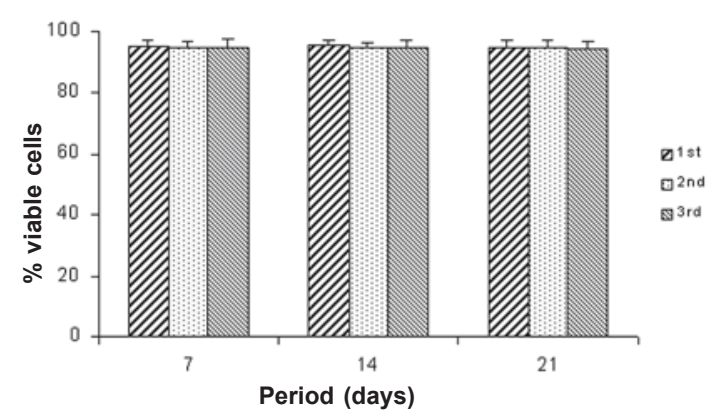

Figure 3. Cell viability expressed as percentage of viable cells at 7,14 and 21 days. Data are reported as means plus or minus the standard deviation $(n=5)$. There were no statistically significant differences among subcultures (1st, 2nd and 3rd) ( $p>0.05)$.
Differences at $\mathrm{p} \leq 0.05$ were statistically significant.

\section{RESULTS}

Cell attachment was not affected by serial subcultures (ANOVA: $\mathrm{F}=1.54 ; \mathrm{df}=2 ; \mathrm{p}=0.12$ ), but it was a time-dependent event (ANOVA: $\mathrm{F}=73.48 ; \mathrm{df}=1$; $\mathrm{p}=0.0001$ ) being greater at $24 \mathrm{~h}$ (Fig. 1). Cell number was increased by serial subcultures (ANOVA: $F=59.97$; $\mathrm{df}=2 ; \mathrm{p}=0.0001)$ in the following order: $1 \mathrm{st}<2 \mathrm{nd}=3 \mathrm{rd}$ (Fig. 2). Cell viability was not affected by either serial subcultures (ANOVA: $\mathrm{F}=0.35 ; \mathrm{df}=2 ; \mathrm{p}=0.71$ ) or period of culture (ANOVA: $\mathrm{F}=0.17 ; \mathrm{df}=2 ; \mathrm{p}=0.85$ ) (Fig. 3). Total protein content was not affected by serial subcultures (ANOVA: $\mathrm{F}=2.00 ; \mathrm{df}=2 ; \mathrm{p}=0.15$ ). Synthesis of the total protein was affected by period of culture (ANOVA: $\mathrm{F}=10.92 ; \mathrm{df}=2 ; \mathrm{p}=0.0002$ ), in the following order: 7 days $<14$ days $=21$ days (Fig. 4 ). ALP activity

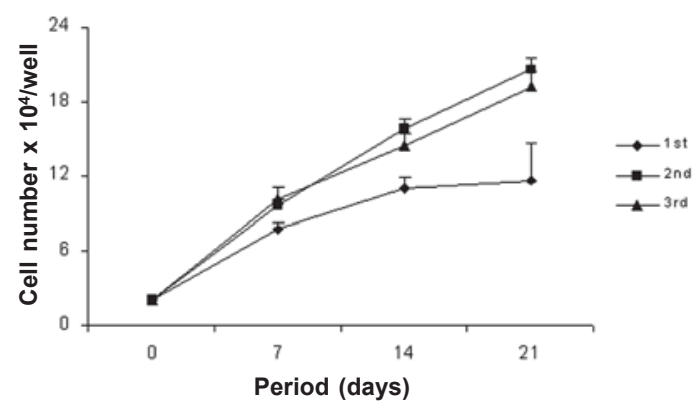

Figure 2. Cell proliferation at 7,14 and 21 days. Data are reported as means plus or minus the standard deviation $(n=5)$. First subculture was statistically significant different from the other subcultures (1st and $2 \mathrm{nd})(\mathrm{p}=0.0001)$.

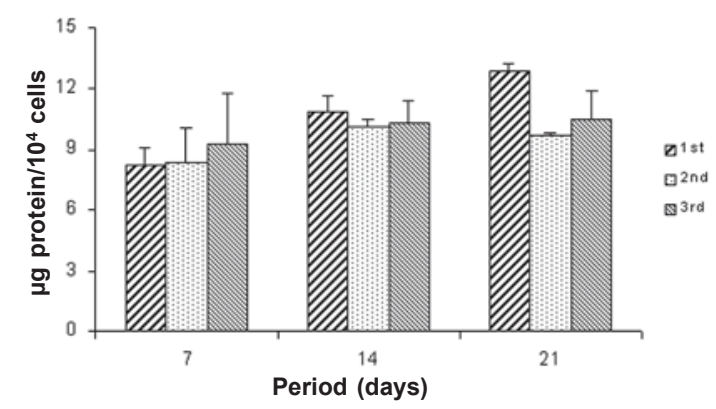

Figure 4. Total protein content $\left(\mu \mathrm{g} / 10^{4}\right.$ cells) at 7, 14 and 21 days. Data are reported as means plus or minus the standard deviation $(n=5)$. There were no statistically significant differences among subcultures (1st, 2nd and 3rd) ( $>>0.05)$. 
was affected by serial subcultures (ANOVA: $\mathrm{F}=103.70$; $\mathrm{df}=2 ; \mathrm{p}=0.0001)$ as follows: $3 \mathrm{rd}<2 \mathrm{nd}<1$ st. It was a time-dependent event (ANOVA: $\mathrm{F}=92.00 ; \mathrm{df}=2$; $\mathrm{p}=0.0001$ ) with peak at the 14th day (Fig. 5). Bone-like formation was affected by serial subcultures (ANOVA:

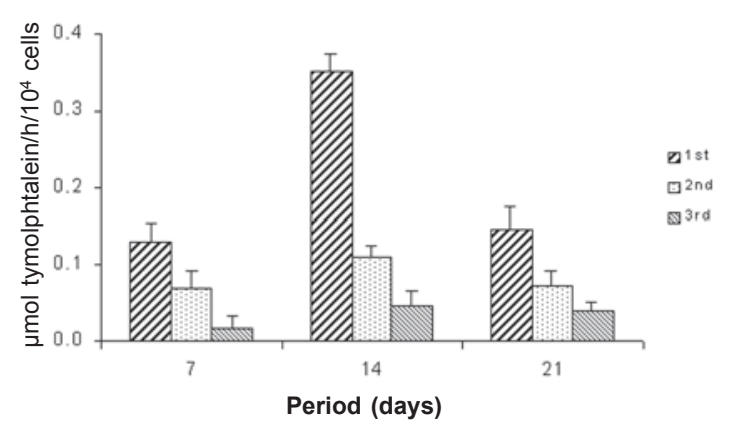

Figure 5. Alkaline phosphatase (ALP) activity ( $\mu \mathrm{mol}$ tymolphtalein $/ \mathrm{h} / 10^{4}$ cells) at 7,14 and 21 days. All data are reported as means plus or minus the standard deviation $(n=5)$. There were statistically significant differences among subcultures in this order: $3 \mathrm{rd}<2 \mathrm{nd}<1 \mathrm{st}(\mathrm{p}=0.0001)$.

\section{DISCUSSION}

Cells isolated from bone marrow provide an excellent source of proliferative osteoprogenitor cells that can be induced to differentiate into osteoblasts (15). Differentiation of osteoblasts has been modeled as a three-step process consisting of a proliferation phase, a matrix maturation phase and a mineralization phase (16). In this study, the behavior of serially subcultured human bone marrow cells largely applied in in vitro studies of bone biology was compared. The present results showed that serial subcultures resulted in cells progressively less differentiated as to osteoblast phenotype.

The biocompatibility of materials is very closely related to cell behavior in contact with them. Cell adhesion is probably the single most important aspect of cell interaction with a biomaterial because it is a prerequisite for further cellular activities, such as spreading, proliferation and differentiation (17). However, the lack of differences in initial cell adhesion to the substrata does not necessarily mean that other cell
$\mathrm{F}=103.70 ; \mathrm{df}=2 ; \mathrm{p}=0.0001$ ), in the following order: $3 \mathrm{rd}$ $<2$ nd $<1$ st. There was no bone-like formation on 3rd subculture. Bone-like formation process increased in a time-dependent way (ANOVA: $\mathrm{F}=112.73 ; \mathrm{df}=1$; $\mathrm{p}=0.0001$ ), being greater at 21 st day (Fig. 6).

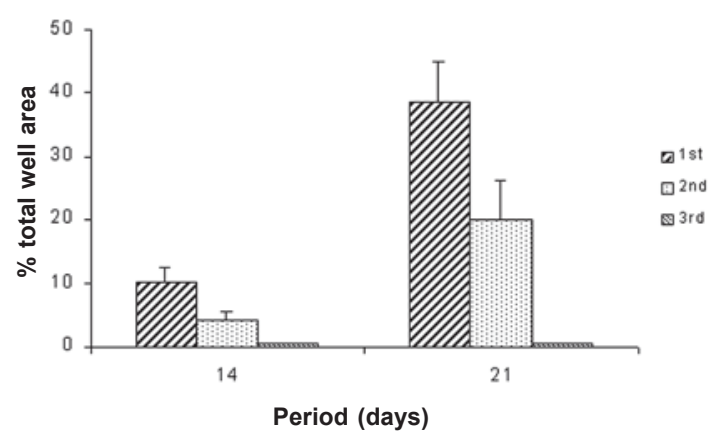

Figure 6. Bone-like formation expressed as a percentage of mineralized area at 14 and 21 days. Data are reported as means plus or minus the standard deviation $(n=5)$. There were statistically significant differences among subcultures in this order: $3 \mathrm{rd}<2$ nd $<1$ st $(\mathrm{p}=0.0001)$.

responses will not be affected by the culture conditions. Therefore, it is also important to investigate the cell behavior at later time points (3). Accordingly, in the present study the percentage of attached cells was similar in different subcultures when the number of cells was counted at the 4-h and 24-h incubation periods following cell inoculation, but markers of osteoblastic differentiation were different in these subcultures. Although cell attachment has not been affected by the different subcultures, it was a time-dependent process as there were more attached cells at $24 \mathrm{~h}$ than at $4 \mathrm{~h}$ of incubation in all evaluated subcultures.

Results of cell proliferation showed that serial cell passage affected the number of cells counted at 7 , 14 and 21 days. Throughout the evaluated period, cell growth was significantly higher in second and third subcultures. In addition, first subculture presented a different pattern of cell proliferation when compared to the second and third subcultures. First subculture raised the plateau from day 14 onwards, whereas in second and third subcultures a trend for a continuous cell growth was observed during the evaluated period. This 
pattern of cell growth was also shown by Coelho et al. (10). However, in contrast with our results, Bruder et al. (11) observed an active proliferation in the first subculture during approximately 3 weeks and a significantly decreased in cell growth after this period. An explanation for such discrepancy could be the use of different methodologies, i.e., while cell counting was done with a hemacytometer in our study, those authors estimated cell growth through a biochemical assay. In spite of affecting cell proliferation, serial cell subcultures did not affect cell viability, as shown by trypan blue, which stains nonviable cells.

In general, cell synthesis activity is sensitive to the serial cell subcultures (10). In the present study, it was observed that total protein content per cell was not affected by the serial subcultures. However, based on both the lower bone-like formation on second subculture and the lack of bone-like formation on third subculture, the composition of protein produced in this subculture could be different from that of the first and second subcultures, which presented bone-like formation at 14 and 21 days, respectively.

ALP activity is used as a marker of osteoblast phenotype and it has been implicated in the initiation of mineralization by hydrolyzing the $\beta$-glycerophosphate present in the culture medium to produce high levels of local phosphate ions providing the chemical conditions for mineral deposition (18). The production of ALP activity by human bone cells is detectable from approximately day 4 onwards, rising to a peak from day 10 onwards (18). In accordance with this, the maximum APL activity was observed at day 14 in all subcultures evaluated in this study. Lesser ALP activity was observed in the second and third subcultures, suggesting that cells of these subcultures lost, at least partially, their capacity to differentiate into osteoblasts. These findings are also consistent with those reported by Coelho et al. (10), although they did not observed a peak of ALP activity at the same time-point for all subcultures. In contrast, DiGirolamo et al. (19) found that cells retain the ability to differentiate into osteoblasts after extensive proliferation in culture. Considering that in both studies human bone marrow cells were evaluated, these differences could be due to the use of different experimental designs, such as periods of evaluation and methods of subculture.

The results of this study showed that, in agreement with other authors (10) and with our previous results
(20), there was a positive correlation between ALP activity and bone-like formation. Therefore, as the ALP activity, it was observed more bone-like formation in the first subculture. These findings could explain why cell growth stopped after 14 days in the first subculture. Enhancement of ALP activity, accumulation, maturation and mineralization of the extracellular matrix indicates more differentiated cells, which consequently presented a lower cell growth.

Human bone marrow cell cultures have been largely used study bone physiology, pathology and materials biocompatibility. However, according to the literature it remains unclear whether serial cell passage contributes to the loss of capacity of osteoblast differentiation $(10,11,19)$. Taken together, the results of the present study indicate that serial subcultures interfere negatively with osteoblast differentiation as shown by second and third subcultures, such as continuous cell proliferation, lower ALP activity and bone-like formation compared to the first subculture. Therefore, it is important to evaluate cell ability to growth and differentiate before selecting the cell population for studies that investigate the biocompatibility of materials to replace bone tissue.

\section{RESUMO}

Culturas de células de medula óssea têm sido utilizadas para avaliar a biocompatibilidade de substitutos ósseos que poderiam ser empregados em cirurgias maxilofaciais e ortopédicas. No entanto, ainda não está claro se células em subculturas mantêm a habilidade para se diferenciarem em osteoblastos. O objetivo deste estudo foi comparar o desenvolvimento do fenótipo osteoblástico em subculturas seriadas de células de medula óssea humana. Células da primeira à terceira passagem foram cultivadas ( $2 \times 10^{4}$ células/poço) em $\alpha$-MEM suplementado. As células foram incubadas a $37^{\circ} \mathrm{C}$ e $5 \% \mathrm{CO}_{2} / 95 \%$ ar atmosférico. A adesão celular foi avaliada em $4 \mathrm{~h}$ e 24 h. Aos 7, 14 e 21 dias, a proliferação e viabilidade celulares, conteúdo de proteína total e atividade de fosfatase alcalina (ALP) foram avaliadas. A formação de matriz mineralizada foi avaliada aos 14 e 21 dias. Os dados foram comparados por análise de variância a dois critérios e teste de Duncan. Adesão e viabilidade celular e conteúdo de proteína total não foram afetados pela subcultura seriada. Entretanto, a subcultura seriada interferiu negativamente na diferenciação osteoblástica, como demonstrado pelos parâmetros osteoblásticos da segunda e terceira passagens, tais como a proliferação celular contínua, a baixa atividade de ALP e a baixa quantidade de matriz mineralizada formada, quando comparados à primeira passagem. Portanto, é importante avaliar a capacidade das células para se diferenciarem em osteoblastos antes de selecionar a população de células adequada para testar a biocompatibilidade de materiais para substituir tecido ósseo. 


\section{REFERENCES}

1. Flynn JM, Shelton RM, Landini G. Investigation of primary cell-biomaterial interactions using silver nitrate staining of the nucleolar organising regions. Biomaterials 2002;23:1926.

2. Pizzoferrato A, Ciapetti G, Stea S, Cenni E, Arciola CR, Granchi D, Savariano L. Cell culture methods for testing biocompatibility. Clin Mat 1994;15:173-190.

3. Beloti MM, Hiraki KRN, Barros VMR, Rosa AL. Effect of chemical composition of Ricinus communis polyurethane on rat bone marrow cell attachment, proliferation, and differentiation. J Biom Mater Res 2003;64:171-176.

4. Rosa AL, Beloti MM. TAK-778 enhances osteoblast differentiation of human bone marrow cells cultured on titanium. Biomaterials 2003;24:2927-2932.

5. Deligianni DD, Katsala ND, Koutsoukos PG, Missirllis YF. Effect of surface roughness of hydoxyapatite on human bone marrow cell adhesion, proliferation, differentiation and detachment strength. Biomaterials 2001;22:87-96.

6. Cooper LF, Masuda T, Ylilheikkila PK, Felton DA. Generalizations regarding the process and phenomenon of osseointegration. Part II. In vitro studies. Int J Oral Maxillofac Implants 1998;13:163-174.

7. Javazon EH, Colter DC, Schwarz EJ, Prockop DJ. Rat marrow stromal cells are more sensitive to plating density and expand more rapidly from single-cell-derived colonies than human marrow stromal cells. Stem Cells 2001;19:219-225.

8. Prockop DJ. Marrow stromal cells for nonhematopoietic tissues. Science 1997;276:71-74.

9. Chavassieux PM, Chenu C, Valentin-Opra A, Merle B, Delmas PD, Hartmann DJ, Saez S, Meunier PJ. Influence of experimental conditions on osteoblast activity in human primary bone cell cultures. J Bone Miner Res 1990;5:337343.

10. Coelho MJ, Cabral AT, Fernandes MH. Human bone cell cultures in biocompatibility testing. Part I: osteoblastic differntiation of serially passaged human bone marrow cells cultured in á-MEM and DMEM. Biomaterials 2000;21:10871094.

11. Bruder SP, Jaiswal N, Haynesworth SE. Growth kinetics, selfrenewal and the osteogenic potential of purified human mesenchymal stem cells during extensive subcultivation following cryopreservation. J Cell Biochem 1997;64:278294.

12. Schmidt R, Kulbe KD. Long-term cultivation of human osteoblasts. Bone Miner 1993;20:211-221.

13. Rosa AL, Beloti MM. Effect of cpTi surface roughness on human bone marrow cell attachment, proliferation, and differentiation. Braz Dent J 2003;14:16-21.

14. Lowry OH, Rosebrough NJ, Farr AL, Randall RJ. Protein measurement with the Folin phenol reagent. J Biol Chem 1951;193:265-275.

15. Peter SJ, Liang CR, Kim DJ, Widmer MS, Mikos AG. Osteoblastic phenotype of rat marrow stromal cells cultured in the presence of dexamethasone, â-glycerolphosphate, and L-ascoric acid. J Cel Biochem 1998;71:55-62.

16. Lian JB, Stein JS. Concepts of osteoblast growth and differentiation: Basis for modulation of bone cell development and tissue formation. Crit Rev Oral Biol Med 1992;3:269305.

17. Kirkpatrick CJ, Dekker A. Quantitative evaluation of cell interaction with biomaterials in vitro. Adv Biomater 1992;10:31-41.

18. Di-Silvio L, Gurav N. Osteoblasts. In: Koller MR, Palsson BO, Masters JRW (Editors). Human Cell Culture. Primary Mesenchymal Cells. Kluwer, Great Britain, 2001;5:221-236.

19. DiGirolamo CM, Stokes D, Colter D, Phinney DG, Class R, Prockop DJ. Propagation and senescence of human marrow stromal cells in culture: a simple colony-forming assay identifies samples with greatest potential to propagate and differentiate. Br J Haematol 1999;107:275-281.

20. Rosa AL, Beloti MM. Rat bone marrow cells response to titanium and titanium alloy with different surface roughness Clin Oral Implants Res 2003;14:43-48. 